\title{
Adult Brain Meningioma
}

National Cancer Institute

\section{Source}

National Cancer Institute. Adult Brain Meningioma. NCI Thesaurus. Code C9374.

A brain meningioma that occurs during adulthood. 